\title{
PREDICTION OF CURRENCY CRISES USING A FISCAL SUSTAINABILITY INDICATOR
}

\author{
PREDICCION DE CRISIS CAMBIARIA USANDO UN INDICADOR DE \\ SOSTENIBILIDAD FISCAL
}

\section{ALEXIS CRUZ-RODRIGUEZ*}

Universidad Católica Santo Domingo

\begin{abstract}
The purpose of this paper is to investigate whether a fiscal sustainability indicator (FSI) can be used as a leading indicator to predict currency crises. Firstly, the sustainability of the fiscal policy in 17 developing countries is analysed using a FSI developed by Croce and Juan-Ramón (2003). Then, the FSI is evaluated in order to help predict currency crises. Using a nonlinear Markov-switching model, and applying the Gibbs sampling approach, it is found that the FSI influences the probability of entering a currency crisis period. Also, in the absence of official definitions for currency crises, different definitions are used to evaluate whether they induce different results in the analysis. In general, the results highlight how an unsustainable fiscal position leads to the eventual collapse of the exchange rate in some developing countries.
\end{abstract}

Keywords: Currency crisis, foreign exchange, fiscal sustainability.

JEL Classification: F31, F33, E62.

\section{Resumen}

El propósito de este trabajo es investigar si un indicador de sostenibilidad fiscal (FSI) puede ser utilizado como indicador líder para predecir crisis cambiarias. Para evaluar esto, en primer lugar se analiza la sostenibilidad

* E-mail: acruz@ucsd.edu.do. I would like to thank Alexandros Mandilaras, Paul Levine, Vasco Gabriel, Keith Pilbeam and José Amado Requena for many helpful comments on the preliminary stages of this paper. All errors are mine. 
de la política fiscal en 17 países en desarrollo, utilizando el indicador de sostenibilidad fiscal desarrollado por Croce y Juan-Ramón (2003). Luego, se utiliza un modelo de Markov con cambio de régimen, aplicando el método de muestreo de Gibbs, para evaluar si el FSI ayuda a predecir crisis cambiarias. Los resultados sugieren que el FSI influye en la probabilidad de entrar en un período de crisis cambiarias. Asimismo, en ausencia de una definición oficial de crisis cambiarias, se usan distintas definiciones con el fin de evaluar si las mismas inducen a diferentes resultados. En general, los resultados ponen de manifiesto cómo una situación fiscal insostenible conduce a un eventual colapso del tipo de cambio en algunos países en desarrollo.

Palabras Clave: Crisis cambiaria, tipo de cambio, sostenibilidad fiscal.

Clasificación JEL: F31, F33, E62.

\section{INTRODUCTION}

Exchange rate collapses and currency crises in developing countries have been the two main subjects in international macroeconomics in the last two decades. Consequently, there has been a resurgence of interest in the early warning systems that can anticipate the occurrence of currency crises. The key to crisis prevention is the early recognition of economic vulnerability to currency crises. Therefore, it is desirable to identify some indicators of vulnerability in order to avert these crises. Some of the recent literatures on the early warning systems (EWS) for currency crises employ leading indicators such as the stock market, sovereign ratings, among others. However, does a fiscal sustainability indicator (FSI) really predict currency crises? Unfortunately, the literature on the subject has paid little attention to the role of FSIs in assessing the probability of currency crises.

The aim of this paper is to assess whether a Fiscal Sustainability Indicator can be used as a leading indicator in predicting currency crises. To do that, the alternative approach proposed by Croce and Juan-Ramón (2003) is employed to measure the fiscal sustainability of each country. Then the Markov-switching model introduced by Albert and Chib (1993), and applying a Gibbs sampling approach is used to evaluate if the Fiscal Sustainability Indicator influences the transition probability of experiencing currency crises. In this sense, the two regimes are defined in the following ways: a tranquil regime as the regime with the smallest mean and crisis regime as the regime with the highest mean.

In addition, two empirical definitions of currency crises are employed. Firstly, a crisis is defined as nominal currency depreciation. Secondly, an exchange market pressure index is constructed as an indicator of currency crises. This indicator is calculated by computing a weighted average of the nominal depreciation rate, the change in interest rates and international reserves using the United States as the 
country of reference. The quarter in which the index exceeds a certain threshold is taken to be the crisis period. Finally, from previously mentioned definitions, two binary definitions of currency crises are constructed.

Quarterly data for a sample of the following 17 developing countries is presented: Argentina, Brazil, Chile, Colombia, Costa Rica, Czech Republic, the Dominican Republic, El Salvador, Honduras, Hungary, Indonesia, Malaysia, Mexico, Peru, Philippines, Thailand and Turkey. This selection of countries has been dictated by data availability. Fiscal policy was also a relevant criterion in terms of public debt and composition and variability of public expenditures in the sample. Most of these countries have experienced episodes of currency crises in the period 1990-2004. Therefore the countries and the period considered provide a good sample to test our hypothesis. It should be emphasised that this paper does not intend to give a detailed overview of the causes and unfolding of currency crises; instead it concentrates primarily on highlighting if the FSI helps to predict currency crises.

The result from a time-varying transition probability (TVTP) Markov-switching model reveals that the inclusion of a Fiscal Sustainability Indicator in the transition probabilities improves the conditional probabilities of a currency crisis.

The remainder of the paper is organised as follows: Section 2 provides a brief review of the literature discussing the fiscal roots of currency crises. Section 3 presents different definitions of currency crises. Section 4 discusses Fiscal Sustainability Indicators and presenting a framework for the TVTP Markov-switching models. Section 5 describes the sets of data obtained. Section 6 presents estimated results and an analysis of these. Finally, Section 7 presents the concluding remarks.

\section{THE ROLE OF FISCAL POLICY IN CURRENCY CRISES: A LITERATURE REVIEW}

Existing literature on currency crises distinguishes between several types of crises according to their causes, fundamentally classifying them into three generations of crises models. The first generation models, called speculative attack models, focus on macroeconomic imbalances (Krugman, 1979, 1996; Flood and Garber, 1984; Flood and Marion, 1996). The second generation models accentuate the self-fulfilling characteristics of a currency crisis and the occurrence of multiple equilibriums (Obstfeld, 1986, 1996; Rangvid, 2001). Finally, third generation models stress the consequences of moral hazards in the banking system and the contagion effect as key determinants of a currency crisis (Chang and Velasco, 2001). Most of the literature on currency crises focuses on the role of monetary policy in a crisis. However, theoretical and empirical literature on currency crises provides a useful framework for the analysis of fiscal causes.

First generation models indicate that an inadequate macroeconomic policy is the main cause of currency crises. According to Krugman (1979), one of the longstanding explanations of currency crises is that they result from immoderate fiscal policies. Inconsistencies between fiscal policy fundamentals and exchange rate regimes lead to the abandonment of certain exchange rate regimes (usually the fixed exchange rate). 
The idea is that a large monetized budget deficit is accompanied by a gradual fall in foreign reserves, and that when the level of foreign reserves becomes low enough, a speculative attack on the currency occurs. At this point speculators purchase the remaining amount of international reserves, forcing the central bank to change the exchange rate regime. Krugman (1979) claims that a currency crisis is caused by a large budget deficit that is financed by credit expansion.

Similarly, Van Wijnbergen (1991) demonstrates how the resulting fiscal inconsistencies lead to international reserve losses and forced devaluations as well as subsequent permanent increases in inflation. This author argues that external shocks can destroy consistency between fiscal programmes and inflation targets, causing foreign reserve losses, exchange rate changes and higher inflation. As a consequence, the balance of payments crises provide the mechanism through which fiscal imbalances translate into higher inflation rates. Contrary to the analysis presented in the literature covering early speculative attacks, a domestic credit policy designed to prevent international reserve losses during a stabilisation programme is shown to be insufficient in preventing speculative attacks under fixed exchange rate regimes.

Recent contributions in the analysis of the fiscal dimension of a currency crisis in light of first generation models come from Daniel (2001); Corsetti and Mackowiak (2005, 2006); Burnside et al. (2003, 2006); among others. ${ }^{1}$ Daniel (2001) analyses the role of fiscal policy in generating exchange rate crises showing that a currency crisis occurs when the fiscal authority allows the present value of primary surpluses, inclusive of seigniorage, to differ from the current value of government debt at the pegged exchange rate. Once fiscal policy violates the constraints imposed by a fixed exchange rate regime, there is no monetary policy consistent with the long-run viability of such regime. Similarly, Corsetti and Mackowiak (2005) construct a framework in order to study currency crises associated with fiscal imbalances. In contrast with most of the literature on speculative attacks and currency collapses, they find that the composition of public liabilities is a key determinant in the macroeconomic dynamics surrounding a crisis, as well as the magnitude of exchange rate adjustments in fiscal imbalances. In the same way, Corsetti and Mackowiak (2006) present a simple framework to analyse the fiscal dimension of a currency crisis. Their analysis can be summarised as follows, with the expansion of domestic credit and seigniorage revenues being a sideshow, a fiscal imbalance can cause the abandonment of a currency peg independently of any need for seigniorage revenues. Their work also illustrates how fiscal and interest rate policies interact to determine the magnitude and the timing of speculative attacks and devaluations. Moreover, Burnside et al. $(2003,2006)$ use a general equilibrium model in which prospective government deficits trigger a currency crisis, and explore the implications of different strategies for financing the fiscal costs associated with a currency crisis for inflation and depreciation rates.

To explain crises in light of second generation models some authors identify changed expectations as the main cause of a currency crisis. These models focus on the role of government choice in setting policy and in the potentially self-fulfilling

1 These contributions are sometimes viewed as an alternative to the Krugman model. 
nature of expectations in using models with multiple equilibria. ${ }^{2}$ These models also emphasise how large scale capital inflows (often attracted by a speculative bubble) turn into pre-crisis outflows. Therefore, crises may occur without the worsening of fundamentals and without inconsistent policies. Attacks on the currency are prompted by a shift in investor sentiment, that is, a shift in market expectations from a good to bad equilibrium (Obstfeld, 1996). The attack takes place when investors obtain new information that the government's net liabilities exceed a threshold, or when the government decides to extract seignorage, instead of embarking on a fiscal adjustment, to meet intertemporal budget constraints. In other words, the immediate cause of a crisis is the signalling that the government can only resolve policy inconsistencies by abandoning exchange rate rules rather than attempting to contain public sector imbalances. Daniel (1997) provides an alternative model to the self-fulfilling crisis explanation for episodes of exchange rate collapses, arguing that instantaneous collapses in exchange rate regimes can be the result of a policy that increases the government's reliance on seigniorage revenues. His work addresses the predictability of exchange rate crises and finds that it is empirically difficult to attribute some recent exchange rate regime collapses to a preceding period of unsustainable government policies.

On the other hand, some authors attempt to identify the fiscal roots of major currency crises using third generation models. These models introduce the role of moral hazards as a cause for excessive borrowing. The moral hazards based models stress the role played by government bailout promises in determining excessive risk-taking by financial intermediaries. Here, a sudden loss of confidence triggers a twin crisis, combining banking and currency problems, once maturity and currency mismatches in banking balance sheets enter a zone of vulnerability. The idea is that, a banking system crisis will lead to a currency crisis using the first generation model mechanism, because government contingent liabilities (implicit guarantees) become commitments in the moments of crisis and result in unsustainable fiscal deficits, with central banks as lenders of last resort. However, the measures taken are inconsistent with the maintenance of fixed exchange rates. Marini and Piersanti (2003) use an optimising general equilibrium model to investigate currency and financial crises in emerging markets. They show that a rise in current and expected future budget deficits generates a real exchange rate appreciation and a depletion of foreign reserves, leading to a currency crisis when reserves decline below critical levels. Similarly, Burnside et al. (2000) explain currency crises as the consequence of expected future budget deficits brought about by the implicit bailout promise for failing banking systems.

In this line of study, Nashashibi and Bazzoni (1993) investigate a sample of 28 sub-Saharan African countries in the period 1980-1991. They find that in those countries where the tax base is highly dependent on imports and import substitutes, exchange rate movements in response to external shocks are critical in sustaining and improving fiscal performances. Eichengreen et al. (1994) present an empirical analysis of speculative attacks on pegged exchange rates in 22 countries between 1967 and 1992. They find that there are links between budget deficits, public debt

2 The existence of multiple equilibriums has been questioned, under specific conditions, by Krugman (1996). 
and the probability of a crisis but only in the non-Exchange Rate Mechanism (ERM) sample. Contrary, Frankel and Rose (1996) using panel data, for over 100 developing countries from 1971 to 1992, show that fiscal deficits tend to be small and shrinking in countries experiencing a crisis. Kaminsky and Reinhart (1999) examine currency and banking crises episodes in 20 countries (industrial and developing) for the period 1970-1995. They find that fiscal deficits tend to be higher in the two years preceding a currency crisis, compared to tranquil periods. Similarly, Aziz et al. (2000) seek to identify common characteristics among a variety of macroeconomic and financial variables for a large sample of currency crises in industrial and emerging countries between 1975 and 1997. They find that fiscal deficits tend to be, on average, larger two years before the crisis occurs across the whole sample.

Siwinska (2000) conducted a comparative analysis related to the fiscal imbalances leading to currency crises. She examined the behaviour of a number of fiscal variables before and during the crisis, compared to tranquil episodes, in 50 developing and transition countries for the period of 1980-1999. For both developing and transition economies, the crisis was preceded by larger than normal fiscal deficits and a higher level of public debt. Additionally, Bird and Mandilaras (2006) find that fiscal imbalances have a significant effect on pressures in the foreign exchange market in Latin American and Caribbean countries but not in the East Asian and Pacific countries. Similarly, Mandilaras and Bird (2008) use panel data (LSDV) and generalised methods of moments (GMM) for 28 Latin American and Caribbean countries showing that accumulated debts increase the pressures in the foreign exchange market.

On the other hand, there have been numerous empirical studies on currency crises, which attempt to deduce the leading indicators that would make currency crises more predictable. Some researchers use exchange rate expectations, overvaluation of currency, and capital controls, among others, as predictors of currency crises (Goldfajn and Valdés, 1997; Burkart and Coudert, 2002). Other studies use stock market and sovereign ratings as leading indicators of currency crises (Broome and Morley, 2004; Sy, 2004). Some of the studies listed employ more than one methodology. However, none of the aforementioned papers considers a Fiscal Sustainability Indicator.

The next section introduces the different currency crisis definitions employed in this paper.

\section{DEFINING CURRENCY CRISES}

The definition of a currency crisis is of paramount importance in the process of identifying the leading indicators for predicting a crisis. Several approaches exist in the literature reviewed. In some theoretical works a currency crisis is predominantly defined only in the case of fixed exchange regimes, usually as the official devaluation or abandonment of the fixed exchange rate regime. However, this definition is not flexible enough to use in empirical studies.

Other empirical studies define a currency crisis as a large (either nominal or real) devaluation or depreciation of the domestic currency. However, this last definition does not consider that monetary authorities can fight a speculative attack by intervening in 
the foreign exchange market or by increasing interest rates. In these circumstances, a currency crisis (defined as a speculative attack) may not lead to an actual devaluation. As a consequence, unsuccessful speculative attacks should be included in the definition of a currency crisis since they point to the vulnerability of the system as seen in a fall in international reserves and a rise in interest rates (Girton and Roper, 1977; Eichengreen et al., 1996). This paper employs different methodologies to define a currency crisis and compares their results. Firstly, an indicator is constructed based on the movements in nominal exchange rates according to the definition of currency crisis proposed by Frankel and Rose (1996). This definition of a currency crisis only encompasses currency devaluation without a decrease in international reserves or an increase in interest rates. We define a crisis as a nominal depreciation of the domestic currency in any quarter greater than $6 \%$, but it also has to exceed the previous year's depreciation level by at least $10 \% .^{3}$ In other words, this definition assumes that there are only successful speculative attacks. This definition is utilised to create a binary variable, a crisis indicator called Exchange Rate Depreciation (ERD), equal to one if a crisis occurs and equal to zero otherwise.

Secondly, a definition of a currency crisis is used to refer to an intense increase in speculative pressure on the country's currency. Therefore, the measure of exchange rate pressure (MPI) developed by Girton and Roper (1977) and modified by Eichengreen et al. (1996) is used. The idea being that a successful speculative attack on a currency would show up in a change in the exchange rate, but that monetary authorities can fend off these attacks either by raising interest rates or by selling off international reserves. The advantage of using this index is that both successful and unsuccessful attacks on a currency can be asserted. Then, a given episode can be classified as a speculative attack or crisis period if the MPI is greater in value than 1.5 standard deviations over the country's own mean value. Mean values and standard deviations are country-specific. As a consequence, the binary variable is used, identifying the speculative attack regime in the sample. ${ }^{4}$

Finally, currency crises are defined employing the Markov-switching approach (with time-varying transition probabilities). The parameters estimated with this method and the data reveal the period of crisis in an economy.

The next section presents the theoretical framework to evaluate the effectiveness of a fiscal sustainability indicator in predicting a currency crisis.

\section{METHODOLOGY}

This section is divided into two sub-sections. The first sub-section, based on Croce and Juan-Ramón (2003), presents a recursive algorithm derived from the law of

\footnotetext{
3 This definition is according to the definitions of currency crises given by Frankel and Rose (1996), which is a depreciation of the exchange rate greater than $25 \%$ in any given year.

4 However, a major drawback in this approach is that the weights, as well as the threshold value used to identify the speculative attacks, are somewhat arbitrary.
} 
motion of the debt to GDP ratio to analyse the sustainability of fiscal policy. Finally, a Markov-switching model (with time-varying transition probabilities) is introduced.

\subsection{Establishing Government Fiscal Sustainability}

To evaluate fiscal sustainability, this paper uses the recursive algorithm developed by Croce and Juan-Ramón (2003). In order to derive a simple expression for the index of fiscal sustainability, it is assumed that the debt ratio (debt to GDP) at time $t-1$ is higher than the long-term objective for that ratio $\left(d_{t-1}>d^{*}\right)$. Hence $d_{t}$ would converge to $d^{*}$, if and only if $\left|\beta_{t}-\lambda_{t}\right|<1$, in which $d_{t}$ is public debt as a proportion of GDP (the law of motion in the debt to GDP ratio), $d^{*}$ is the target debt ratio, and $\beta=\frac{1+r_{t}}{1+g_{t}}, r_{t}$ is the real interest rate and $g_{t}$ denotes the rate of growth of real output. The parameter $\lambda_{t}$ indicates the intensity of the policy response at time $t$, given the debt ratio gap in the previous period. Therefore, we can use $\left(\beta_{t}-\lambda_{t}\right)$ as an indicator of fiscal sustainability. ${ }^{5}$ An alternative expression for the Fiscal Sustainability Indicator (FSI) is accordingly:

$$
F S I_{t}=\left(\beta_{t}-\lambda_{t}\right)=\left(\frac{1+r_{t}}{1+g_{t}}-\frac{p s_{t}-p s^{*}}{d_{t-1}-d^{*}}\right)
$$

where $p s_{t}$ is the ratio of the primary surplus to GDP. This expression states that a persistently higher spread between the observed real interest rate and the observed growth rate of real GDP would, other than being equal, lead to higher public indebtedness (high parameter $\left.\beta_{t}\right) .^{6}$ The second parameter $\left(\lambda_{t}\right)$, measures the ratio between the deviation of observed and target values of the primary surplus and public debt ratios. In addition, a fiscal position would be sustainable if $F S I_{t}<1$. In contrast, if $F S I_{t} \geq 1$ then the fiscal position is unsustainable.

The following sub-section presents the framework for the TVTP Markov-switching model.

\subsection{Markov-Switching Model of Crises with Endogenous Transition Probabilities}

To evaluate the usefulness of a leading indicator in predicting a currency crisis, a Markov-switching model is fitted along the lines of Filardo and Gordon (1998).

\footnotetext{
For a detailed demonstration see Croce and Juan-Ramón (2003).

6 For mature stable economies the expected value $\beta$ should be about 1 , higher than 1 for economies with relative scarce capital and high financial intermediation costs, and much higher than 1 and more volatile in contexts of economic and political uncertainty.
} 
Building on Hamilton (1989) the fixed transition probability matrix assumption is relaxed, allowing the probability to vary with economic fundamentals. ${ }^{7}$ The model with time-varying transition probabilities is obtained by:

$$
Y_{t}=\alpha_{0}+\alpha_{1} S_{t}+\phi_{1} X_{t-1}+\cdots+\phi_{p} X_{t-p}+\varepsilon_{t}, \quad \varepsilon_{t} \sim N\left(0, \sigma^{2}\right)
$$

where $Y_{t}$ denotes a change in the domestic exchange market, $\alpha_{0}$ and $\alpha_{1}$ are scalar parameters, $X_{t}$ is a vector of variables that influences the level of $Y_{t}$, and $\varepsilon_{t}$ is a white noise disturbance term. Following the specifications of Filardo and Gordon (1998), a probit function is defined and incorporated to measure the transition probability matrix at each time $t$. This way, the transition probabilities are a function of an economic indicator variable such as the Fiscal Sustainability Indicator, so that the probabilities are always between 0 and 1 .

The time-varying transition probabilities can be expressed as:

$$
P\left(S_{t}=s_{t} \mid S_{t-1}=s_{t-1}, z_{t}\right)=\left[\begin{array}{cc}
q\left(z_{t}\right) & 1-p\left(z_{t}\right) \\
1-q\left(z_{t}\right) & p\left(z_{t}\right)
\end{array}\right]
$$

and

$$
\begin{aligned}
& P\left(S_{t}=1\right)=P\left(S_{t}^{*} \geq 0\right) \\
& P\left(S_{t}=0\right)=P\left(S_{t}^{*}<0\right)
\end{aligned}
$$

where $S_{t}^{*}$ is a latent variable defined by the following equation:

$$
S_{t}^{*}=\gamma_{0}+\gamma_{z}^{\prime} z_{t}+\gamma_{s} S_{t-1}+u_{t}
$$

in which $z_{t}=\left\{z_{t}, z_{t-1}, \ldots, z_{t-n}\right\}$ is a vector of the variables that influence the transition probabilities with corresponding factor-loading determined by the $\gamma_{z}$ vector of parameters, $\gamma_{0}$ and $\gamma_{s}$ are scalar parameters and $u_{t}$ is a standard normally distributed white noise disturbance. The transition probabilities can then be derived by evaluating the conditional cumulative distribution function for $u_{t}$. Specifically, if the probability of the economy remaining in the crisis period at time $t$ once it is in crisis $\left(S_{t-1}=1\right)$, given the values of $z_{t}$, is $p$, then

7 The time-varying transition probabilities model allows the transition probabilities to rise just before a crisis or tranquil period begins, while the fixed transition probabilities model does not (Filardo, 1994). 


$$
\begin{aligned}
p & \equiv \operatorname{Pr}\left\{S_{t}=1 \mid S_{t-1}=1, z_{t}\right\} \\
& =\operatorname{Pr}\left\{u_{t} \geq-\gamma_{0}-\gamma_{z}^{\prime} z_{t}-\gamma_{s}\right\} \\
& \equiv 1-\Phi_{u \mid z}\left(\gamma_{0}-\gamma_{z}^{\prime} z_{t}-\gamma_{s}\right)
\end{aligned}
$$

where $\Phi_{u \mid z}($.$) denotes the standard normal cumulative density function. Similarly,$ the probability of remaining in a tranquil regime at time $t$, given $z_{t}$ and $S_{t-1}=0$ may be expressed as:

$$
\begin{aligned}
q & \equiv \operatorname{Pr}\left\{S_{t}=0 \mid S_{t-1}=0, z_{t}\right\} \\
& =\operatorname{Pr}\left\{u_{t} \geq-\gamma_{0}-\gamma_{z}^{\prime} z_{t}\right\} \\
& \equiv \Phi_{u \mid z}\left(\gamma_{0}-\gamma_{z}^{\prime} z_{t}\right)
\end{aligned}
$$

Finally, the time-varying transition probability matrix can be expressed as:

$$
\left[\begin{array}{cc}
\Phi_{u \mid z}\left(\gamma_{0}-\gamma_{z}^{\prime} z_{t}\right) & \Phi_{u \mid z}\left(\gamma_{0}-\gamma_{z}^{\prime} z_{t}-\gamma_{s}\right) \\
1-\Phi_{u \mid z}\left(\gamma_{0}-\gamma_{z}^{\prime} z_{t}\right) & 1-\Phi_{u \mid z}\left(\gamma_{0}-\gamma_{z}^{\prime} z_{t}-\gamma_{s}\right)
\end{array}\right]
$$

It should be noted that the time-varying transition probability matrix describes how exogenous variables, represented here by $z_{t}$, affect the path of the transition probability remaining in a tranquil period (which corresponds to $S_{t}=0$ ). Associating the crisis period with state $1, p$ becomes the probability of remaining under a crisis regime, where $1-p$ represents that of switching to a tranquil regime. In these terms, exogenous variables inciting currency crises are expected to boost the probability of remaining in a crisis regime $(p)$ as well as that of switching from a tranquil to a crisis regime $(1-p)$. On the other hand, estimates of the parameter vector $\left(\alpha_{0}, \alpha_{1}, \gamma_{0}, \gamma_{z}^{\prime}, \gamma_{s}, \sigma^{2}\right)^{\prime}$, together with the estimated time series for unobservable $S_{t}, S_{t}^{*}, p_{t}$ and $q$, can be carried out in a Bayesian context using an application of the Gibbs sampler, as suggested by Filardo y Gordon (1998).

\section{EMPIRICAL RESULTS}

This section starts with an analysis of the fiscal sustainability results, in addition to the calculated estimates using the Markov-switching model. 


\subsection{Sustainability Assessments}

To construct a Fiscal Sustainability Indicator (FSI), we use $d^{*}$ equal to the lowest value reached by the debt ratio during the period under study. The value of $\beta^{*}$ represents the median of the distribution of the observed values of $\beta$ for the group of developing countries. Its value was set at 1.026 . This implies that the expected value of the real interest rate is 2.6 percentage points higher than the real growth rate, in a steady state.

Table 1 shows the countries with problems of fiscal sustainability during 1990Q12004Q4. Countries for which the FSI was above the threshold of 1 at least $75 \%$ of the times were classified as having been fiscally unsustainable $(\beta-\lambda>1)$ during the period considered. Also, Table 1 shows the frequency of $\beta$ values being higher than $\beta^{*}$, and the frequency of $\lambda$ assuming a negative value (implying primary deficit). In general, the developing countries in the sample present an unsustainable fiscal stance explained mostly by government fiscal deficit rather than spreads between the real interest rates and the growth rates.

TABLE 1

ANALYSIS OF FISCAL SUSTAINABILITY INDICATORS

\begin{tabular}{|lccc|}
\hline & \multicolumn{3}{c|}{ Frequency } \\
\cline { 2 - 4 } Country & $\beta-\lambda>1$ & $\beta>\beta^{*}$ & $\lambda<0$ \\
\hline Argentina & $87 \%$ & $42 \%$ & $95 \%$ \\
Brazil & $62 \%$ & $42 \%$ & $60 \%$ \\
Chile & $33 \%$ & $3 \%$ & $33 \%$ \\
Colombia & $93 \%$ & $37 \%$ & $100 \%$ \\
Costa Rica & $100 \%$ & $2 \%$ & $100 \%$ \\
Czech Republic & $95 \%$ & $20 \%$ & $84 \%$ \\
Dominican Republic & $40 \%$ & $20 \%$ & $40 \%$ \\
El Salvador & $97 \%$ & $3 \%$ & $100 \%$ \\
Honduras & $98 \%$ & $13 \%$ & $100 \%$ \\
Hungary & $95 \%$ & $30 \%$ & $97 \%$ \\
Indonesia & $50 \%$ & $2 \%$ & $60 \%$ \\
Malaysia & $47 \%$ & $7 \%$ & $77 \%$ \\
Mexico & $83 \%$ & $18 \%$ & $85 \%$ \\
Peru & $80 \%$ & $42 \%$ & $93 \%$ \\
Philippines & $98 \%$ & $10 \%$ & $100 \%$ \\
Thailand & $38 \%$ & $13 \%$ & $38 \%$ \\
Turkey & $100 \%$ & $50 \%$ & $100 \%$ \\
\hline Developing Countries & $76 \%$ & $21 \%$ & $80 \%$ \\
\hline
\end{tabular}

Note: Number of quarters as a percentage of total quarters.

Source: Author's calculations. 
In summary, Argentina, Colombia, Costa Rica, the Czech Republic, El Salvador, Honduras, Hungary, Mexico, Peru, Philippines and Turkey present large unsustainable fiscal positions in most of the period studied, which is explained basically by primary fiscal deficit.

The following sub-section presents a Markov-switching model with time-varying transition probabilities.

\subsection{TVTP Markov-switching Model}

This sub-section tests whether the Fiscal Sustainability Indicator (FSI) predicts the switch from tranquil periods to crises episodes. The method used to estimate the Markov-switching model with time varying transition probabilities is the Gibbs sampling approach of Albert and Chib (1993). ${ }^{8}$ Gibbs sampling is an estimated and a simulation technique, based on the properties of Markov chains, for generating random variables from a distribution indirectly without having to calculate the density. ${ }^{9}$ This methodology possesses important advantages over the maximum likelihood framework given that the simulation output gives much more information about the parameters than the maximum likelihood approach.

The Bayesian Gibbs sampling approach is used to find the marginal posterior distributions of the parameters of the model given by equations from 2 to 7 . Before this, it is necessary to assign initial values for some parameters; hence the Quasi Bayesian maximum likelihood algorithm proposed by Hamilton $(1989,1991)$ is used to estimate the priors' parameters. The priors used are presented in Table 2. The parameters $\sigma^{2}, \alpha_{0}$ and $\alpha_{1}$, denote the variances and the means in crisis and tranquil periods respectively. ${ }^{10}$ Then, the model using Gibbs sampling is estimated, setting the priors to the values obtained from the Quasi Bayesian maximum likelihood algorithm. The first 2000 iterations of the Gibbs sampling are discarded to ensure that approximate convergence is obtained. An additional 8,000 iterations are saved and used to draw inferences on the parameters and the switching states. We use the binary index of currency crises as the state variable, the Fiscal Sustainability Indicator as the independent and the MPI as the dependent variable.

The outcomes of the Gibbs sampling simulations, conducted for priors probabilities, are shown in Tables 3 and 4 , where the means $\left(\alpha_{0}\right.$ and $\left.\alpha_{1}\right)$ are negative and positive, respectively, suggesting that the phases represent tranquil and crisis periods. A crisis

8 All results presented in this section were estimated by Bayesian methods and Gibbs sampling using a modified version of Filardo and Gordon (1998) code written by Martin Ellison and available at http:// www2.warwick.ac.uk/fac/soc/economics/staff/ellison/.

9 For a detailed demonstration of Gibbs sampling see Casella and George (1992), and Albert and Chib (1993).

10 In the long run initial values play no role, but good initial values can speed up the convergence of the Markov chain in its ergodic distribution. 
TABLE 2

PRIORS FOR THE PARAMETERS

\begin{tabular}{|c|c|c|c|}
\hline Country & Parameters & Mean & $\begin{array}{c}\text { Standard } \\
\text { Deviation }\end{array}$ \\
\hline Argentina & $\begin{array}{l}\alpha_{0} \\
\alpha_{1}\end{array}$ & $\begin{array}{l}-2.568 \\
15.403\end{array}$ & $\begin{array}{l}8.468 \\
8.468\end{array}$ \\
\hline Brazil & $\begin{array}{l}\alpha_{0} \\
\alpha_{1}\end{array}$ & $\begin{array}{r}-1.412 \\
1.412\end{array}$ & $\begin{array}{l}1.394 \\
1.394\end{array}$ \\
\hline Chile & $\begin{array}{l}\alpha_{0} \\
\alpha_{1}\end{array}$ & $\begin{array}{r}-3.840 \\
1.770\end{array}$ & $\begin{array}{l}0.134 \\
0.134\end{array}$ \\
\hline Colombia & $\begin{array}{l}\alpha_{0} \\
\alpha_{1}\end{array}$ & $\begin{array}{r}-0.717 \\
3.724\end{array}$ & $\begin{array}{l}0.932 \\
0.932\end{array}$ \\
\hline Costa Rica & $\begin{array}{l}\alpha_{0} \\
\alpha_{1}\end{array}$ & $\begin{array}{r}-1.599 \\
1.181\end{array}$ & $\begin{array}{l}0.347 \\
0.347\end{array}$ \\
\hline Czech Republic & $\begin{array}{l}\alpha_{0} \\
\alpha_{1}\end{array}$ & $\begin{array}{r}-0.702 \\
0.355\end{array}$ & $\begin{array}{l}2.278 \\
2.278\end{array}$ \\
\hline Dominican Republic & $\begin{array}{l}\alpha_{0} \\
\alpha_{1}\end{array}$ & $\begin{array}{l}0.800 \\
0.800\end{array}$ & $\begin{array}{l}0.800 \\
0.800\end{array}$ \\
\hline El Salvador & $\begin{array}{l}\alpha_{0} \\
\alpha_{1}\end{array}$ & $\begin{array}{r}-1.729 \\
1.729\end{array}$ & $\begin{array}{l}0.335 \\
0.335\end{array}$ \\
\hline Honduras & $\begin{array}{l}\alpha_{0} \\
\alpha_{1}\end{array}$ & $\begin{array}{r}-0.261 \\
0.290\end{array}$ & $\begin{array}{l}0.261 \\
0.261\end{array}$ \\
\hline Hungary & $\begin{array}{l}\alpha_{0} \\
\alpha_{1}\end{array}$ & $\begin{array}{r}-2.136 \\
0.545\end{array}$ & $\begin{array}{l}0.167 \\
0.167\end{array}$ \\
\hline Indonesia & $\begin{array}{l}\alpha_{0} \\
\alpha_{1}\end{array}$ & $\begin{array}{r}-1.173 \\
7.054\end{array}$ & $\begin{array}{l}1.139 \\
1.139\end{array}$ \\
\hline Malaysia & $\begin{array}{l}\alpha_{0} \\
\alpha_{1}\end{array}$ & $\begin{array}{r}-0.150 \\
0.046\end{array}$ & $\begin{array}{l}1.048 \\
1.048\end{array}$ \\
\hline Mexico & $\begin{array}{l}\alpha_{0} \\
\alpha_{1}\end{array}$ & $\begin{array}{r}-0.793 \\
11.538\end{array}$ & $\begin{array}{l}5.272 \\
5.272\end{array}$ \\
\hline Peru & $\begin{array}{l}\alpha_{0} \\
\alpha_{1}\end{array}$ & $\begin{array}{r}-1.410 \\
1.410\end{array}$ & $\begin{array}{l}0.859 \\
0.859\end{array}$ \\
\hline Philippines & $\begin{array}{l}\alpha_{0} \\
\alpha_{1}\end{array}$ & $\begin{array}{r}-0.211 \\
0.199\end{array}$ & $\begin{array}{l}0.257 \\
0.257\end{array}$ \\
\hline Thailand & $\begin{array}{l}\alpha_{0} \\
\alpha_{1}\end{array}$ & $\begin{array}{r}-0.467 \\
0.132\end{array}$ & $\begin{array}{l}0.928 \\
0.928\end{array}$ \\
\hline Turkey & $\begin{array}{l}\alpha_{0} \\
\alpha_{1}\end{array}$ & $\begin{array}{l}-2.210 \\
11.273\end{array}$ & $\begin{array}{l}5.250 \\
5.250\end{array}$ \\
\hline
\end{tabular}

Note: The prior distribution of $\sigma^{2}$ is improper.

Source: Author's calculations. 


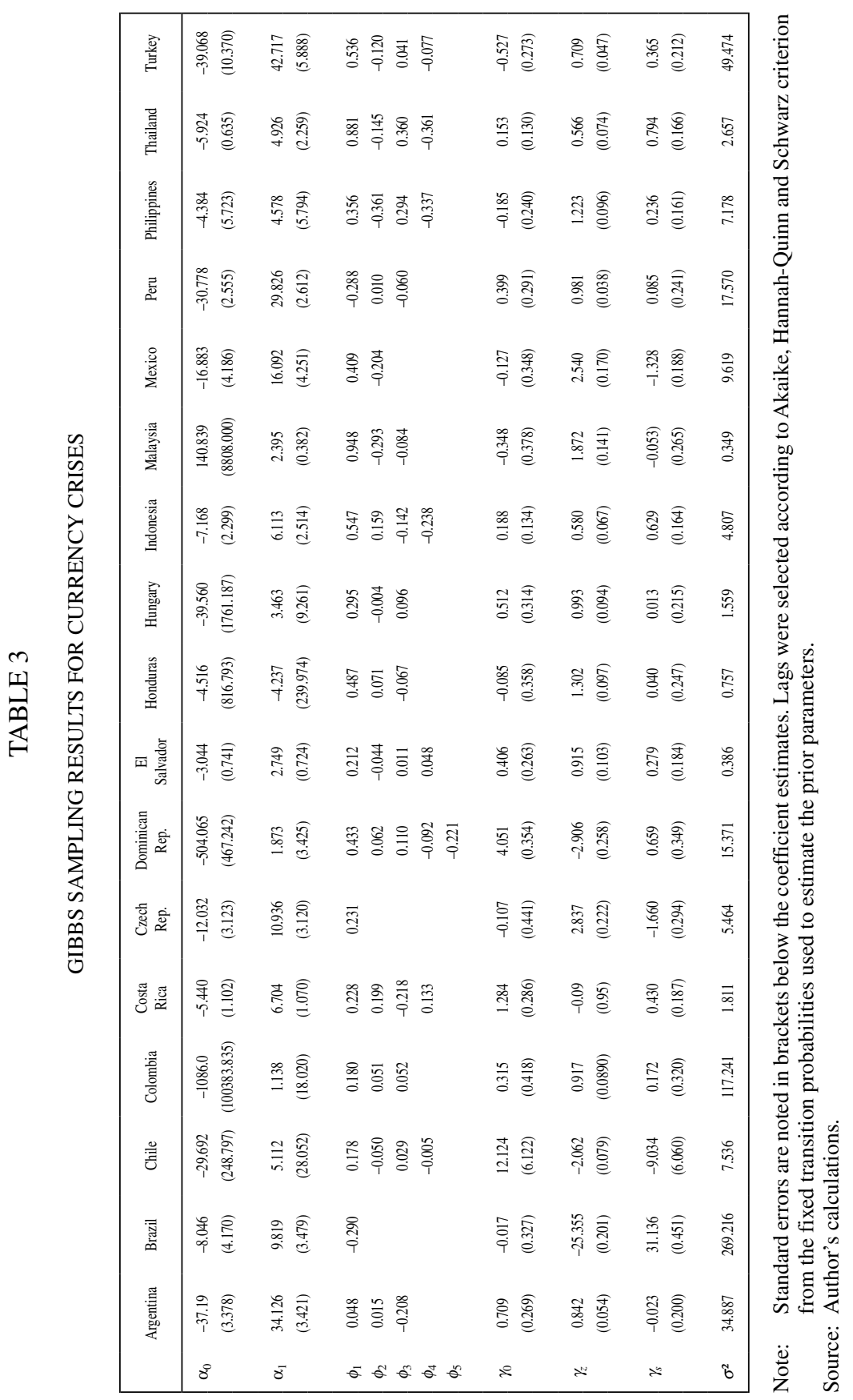




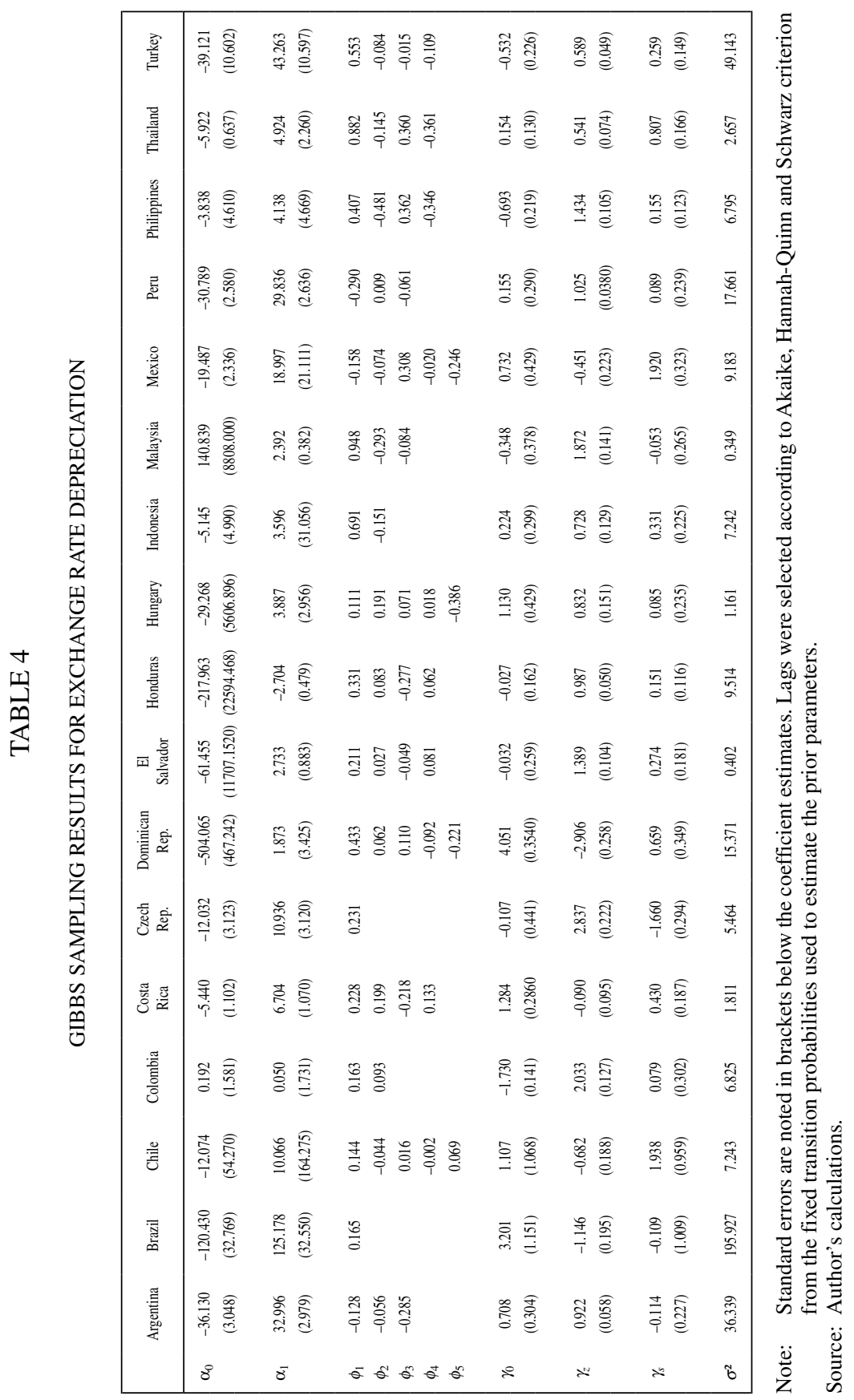


or speculative attacks are identified using the MPI as time series subject to discrete shifts in regimes. We assume a "tranquil" regime takes places when exchange rates, foreign reserves and interest rates are stable, and a "speculative" or "crisis" regime is characterised by large depreciations in exchange rates, foreign reserve falls and interest rates increments. The parameter $\sigma^{2}$, denotes the variances; $\gamma_{z}$ is state dependent slope parameter reflecting the lagged Fiscal Sustainability Indicator information about the likelihood of the economy remaining in or exiting from a crisis period; the parameters $\gamma_{0}$ and $\gamma_{s}$ determine the unconditional mean duration of tranquil periods and crisis regimes. It was expected that $\gamma_{0}>\gamma_{s}$, which implies that the duration of tranquil state is greater than a crisis state; and $\phi$ 's are autoregressive parameters. Lags were selected according to standard information criteria (Akaike, Hannah-Quinn and Schwarz) from the fixed transition probabilities used to estimate the prior parameters. The results are extremely encouraging in that all of the estimated coefficients are statistically significantly different from zero and their sign in most cases accords with our economic intuition. ${ }^{11}$ Figures 1 and 2 plot the smoothed probabilities of currency crises against time $t$.

The results for Argentina show that a switch into a crisis regime entails a jump of about $34 \%$. With regards to the latent variable equation, the estimated coefficient for the Fiscal Sustainability Indicator is also strongly significant and shows, as expected, a positive sign. It is also found that a positive relationship between the probability of being in crisis and the FSI when we use the binary definition of a crisis from the indicator of exchange rate depreciation is used. Based on the two binary crisis definitions used in this section, three currency crises have been identified for Argentina in the period under review (see Figures 1 and 2). Parameters $\gamma_{0}$ and $\gamma_{s}$ capture the asymmetry that tranquil periods tend to last longer than crises periods. In contrast, the results for Brazil show that there is no positive relationship between the Fiscal Sustainability Indicator and currency crises. In other words, the movements of the FSI cannot be used to predict the switch from tranquil periods to crises states. Similarly, for Chile an increase in the value of the FSI reduce the probability of crises. At this point, it is important to point out that Brazil and Chile are not countries fiscally unsustainable during the period considered, according to the results in Table 1.

On the other hand, the results for Colombia show that the estimated coefficient $\gamma_{z}$ is positive, which confirms that an unsustainable fiscal position is associated with a higher probability of switching to a crisis period. At the same time, the parameter $\gamma_{z}$ has an estimated coefficient of variation of about 0.17 when we use binary currency crises, and about 0.30 when we use the binary exchange rate depreciation. According to the parameters $\gamma_{0}$ and $\gamma_{s}$, tranquil periods are longer than currency crisis periods, but these results change when we use the exchange rate depreciation. In the case of

11 A sensitivity analysis is performed to determine if the posterior distributions of parameters are invariant under various sets of priors. The results are not dependent on the priors selected. 
Costa Rica, the results indicate that a switch into the crisis regime entails a jump of about $6.7 \%$, but there is not a positive relationship between the probability of being in crisis and the Fiscal Sustainability Indicator. In contrast, the TVTP Markov-switching model for the Czech Republic yields a high value of $\alpha_{1}$ (about 10.9\% in both cases). Equally, the positive sign for $\gamma_{z}$ is consistent with the belief that an increment in the value of the FSI increases the probability of remaining in a crisis state and decreases the probability of a switch to a tranquil period. The estimated results for the Dominican Republic show that coefficients of $\gamma_{z}$ are negative and tranquil periods are longer than crises regimes.

According to the results for El Salvador, the FSI helps to predict a switch from tranquil periods to crisis states. The parameters $\gamma_{z}$ are significantly positive and have estimated coefficients of variations of about 0.10 . In this way, about three currency crises have been identified for El Salvador in the period under study (see Figures 1 and 2). This country presents currency crises before adopting the US dollar as legal tender. While for Honduras, the parameter $\gamma_{z}$ shows the right sign. However, the results do not present crisis periods. Conversely, for Hungary, the results indicate that there is a direct relationship between the probability of remaining in a currency crisis regime and the FSI.

Results for Indonesia show that the mean of the regime zero is significantly negative, implying a tranquil regime (appreciation in currency or gains in reserves). While, regime one is significantly positive, indicating a crisis state (depreciation or losses in reserves). The positive sign in the parameter $\gamma_{z}$ indicates that an unsustainable fiscal position increases the probability of being in a currency crisis regime. In addition, the estimated parameters $\gamma_{0}$ and $\gamma_{1}$ show that crisis period are longer than tranquil states. Similarly, for Malaysia the estimates indicate that there is a positive relationship between the Fiscal Sustainability Indicator and the probability of currency crises. However, the results show no tranquil periods. ${ }^{12}$ It is also observed that using both crisis definitions leads to identical results. For Mexico, the results show that the probability of being in a crisis state increases as the value of the FSI increases. But this relationship is inversed when we use the exchange rate depreciation, while crisis periods are much deeper than tranquil regimes.

According to the results for Peru, an increase in the Fiscal Sustainability Indicator decreases the probability of remaining in a tranquil period and increases the probability of remaining in a crisis state. Also, tranquil periods are longer than currency crises regimes. Similarly, the results for the Philippines indicate that the FSI can predict the probability of being in a currency crisis state. In addition, the parameters $\gamma_{0}$ and $\gamma_{s}$ indicate that crises regimes are longer than tranquil periods.

12 According to the results for Malaysia, it can be said that this country presents deep crisis and less deep crisis periods. 


\section{FIGURE 1}

\section{SMOOTHED PROBABILITIES OF CURRENCY CRISES}
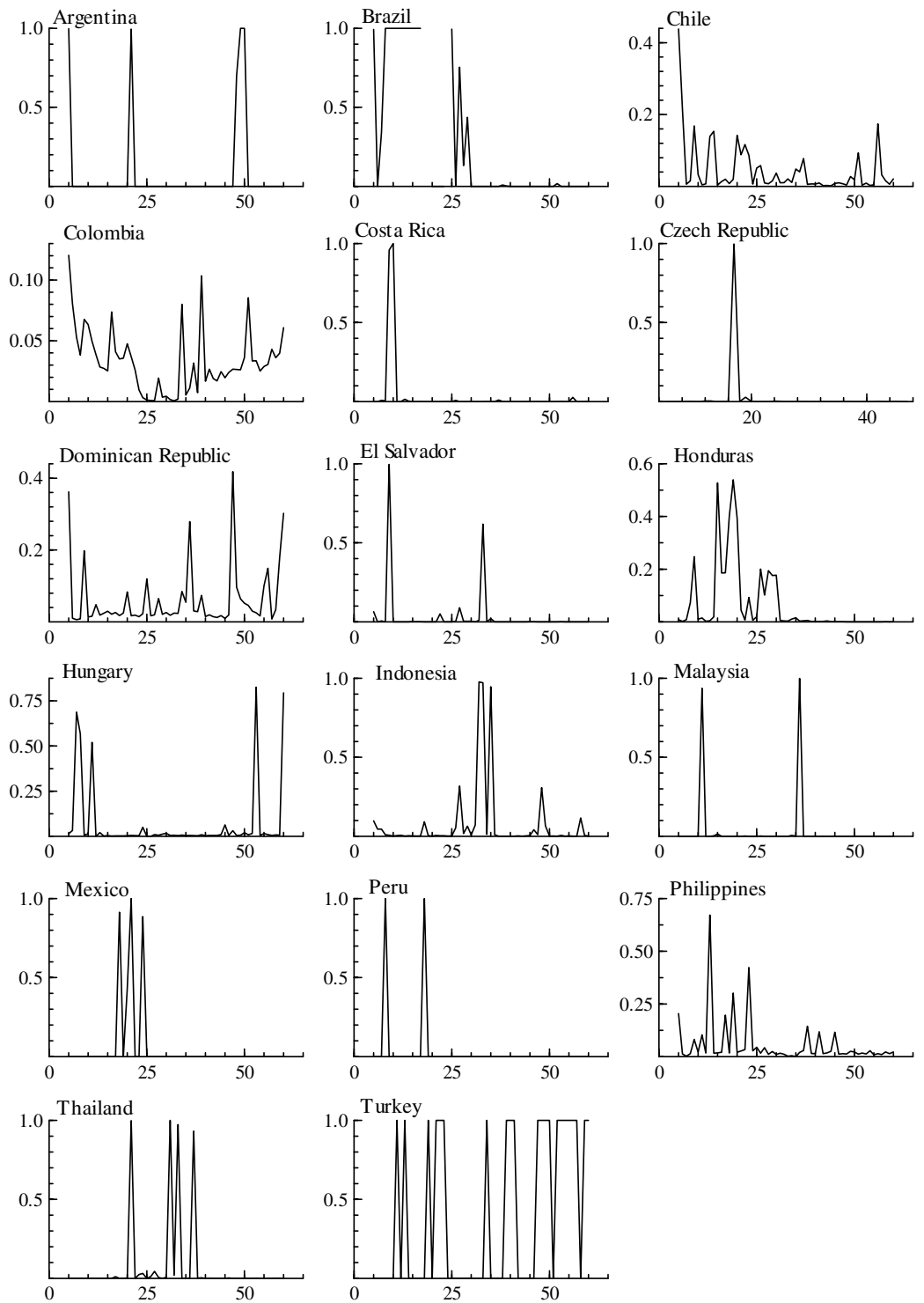

Note: The values of 25 and 50 correspond to the quarters of 1996.01 and 2002.02, respectively. Source: Author's calculations. 


\section{FIGURE 2}

\section{SMOOTHED PROBABILITIES OF EXCHANGE RATE DEPRECIATION}
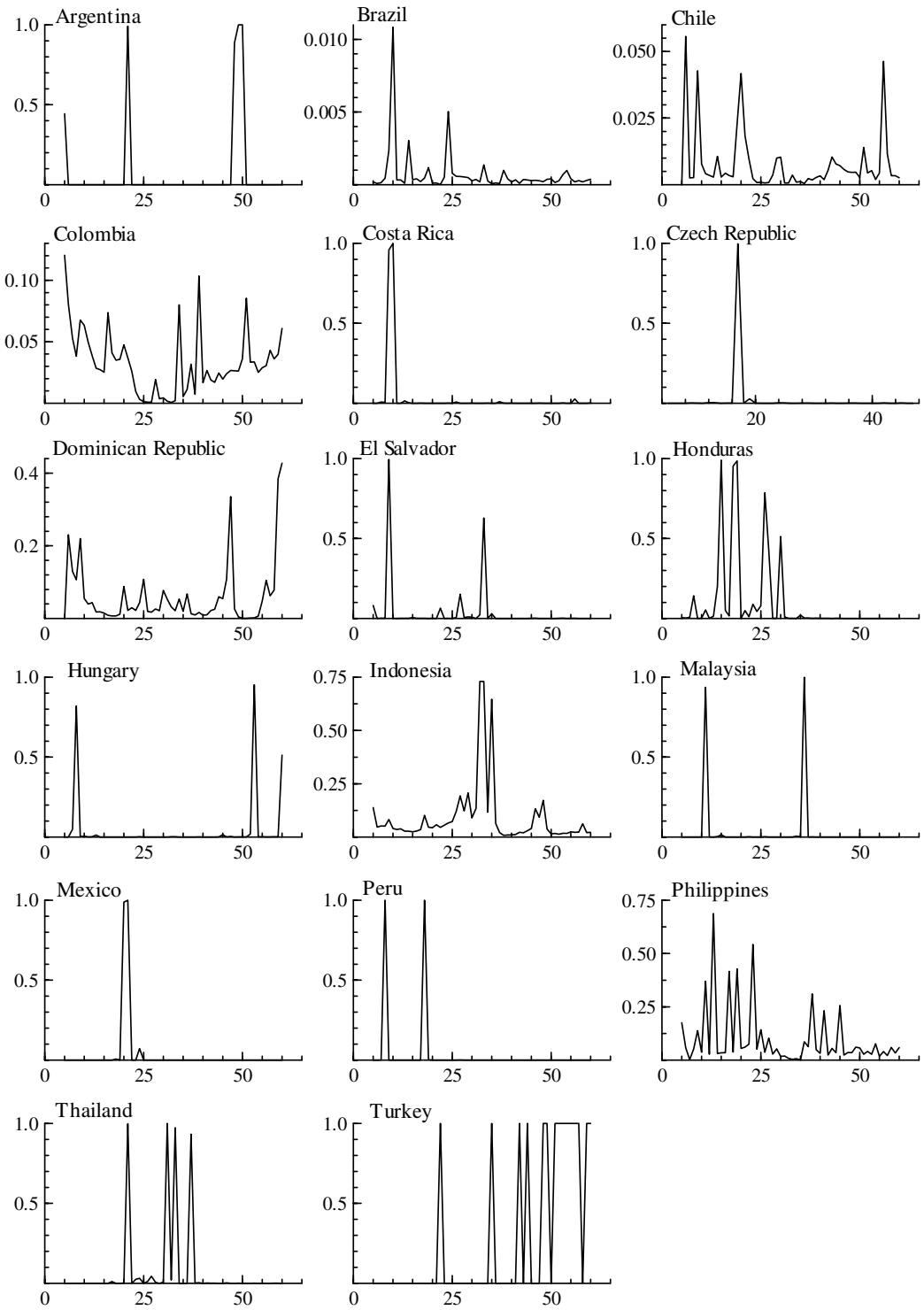

Note: The values of 25 and 50 correspond to the quarters of 1996.01 and 2002.02, respectively. Source: Author's calculations. 
In Thailand's case, the results show that there is a positive relationship between the FSI and currency crises. Also, the mean average duration of the crisis regime is almost 5 quarters. According to the estimated parameters $\gamma_{0}$ and $\gamma_{s}$, crisis periods are longer than tranquil regimes. Similarly, for Turkey, the results indicate that there is a positive relationship between the probability of being in a crisis regime and the FSI. In addition, the parameters $\gamma_{0}$ and $\gamma_{s}$ present those crises states are longer than tranquil periods.

In most cases, the estimated parameters are quite robust. The Fiscal Sustainability Indicator, in most countries, influences the probability of being in a currency crisis period. These results could reflect the nonlinear effect of lagged Fiscal Sustainability Indicator on currency crises.

\section{CONCLUDING REMARKS}

This paper addresses the issue of the leading indicators that can anticipate the occurrence of currency crises. None of the previous empirical studies have focused on whether a Fiscal Sustainability Indicator may predict a currency crisis. This work attempts to bridge this gap. Firstly, a Fiscal Sustainability Indicator has been constructed for 17 developing countries and classified the countries for which the FSI was above the threshold of 1 at least $76 \%$ of the time as having been fiscally unsustainable, and then different measures of currency crises are defined. 11 countries were identified as presenting large unsustainable fiscal positions in most of the period studied, explained basically by primary fiscal deficit.

Finally, a Markov-switching method with time varying transition probabilities is used to test whether the FSI predicts a switch from tranquil to crises periods. Results suggest that in some of the countries considered, the FSI is useful in predicting the probabilities of being in currency crises periods. In general, major currency crises (such as those in South-East Asia in 1997) are well identified by the Markov-switching models. In the case of Chile, this country shows small periods of unsustainable fiscal positions. As a consequence, the Markov-switching model presents a negative link between these variables. The speculative pressure in the Chilean exchange market could be explained perhaps by contagion from Argentina and/or Brazil. The Markovswitching model is also very useful in determining the duration of currency crises periods. Expected duration of a currency crisis in Colombia is 1.21 quarters, while expected duration of a currency crisis in Indonesia is 2.70 quarters.

This paper contributes to the empirical literature on currency crises by proposing a FSI to predict currency crises and using a Markov-switching model with time varying transition probabilities, estimated by the Bayesian Gibbs sampling approach, as an alternative to more standard practice. The Fiscal Sustainability Indicator could act as an important early warning system. However, in light of our results, it has a number of limitations, mainly relating to the individual nature of most currency crises, where different institutional and political factors affect the crises in different ways. The diversity and nature of currency crises determinants reinforces the view that country 
specific models are required. Also, the absence of additional control variables in the TVTP model could affect the results but there is no way we can incorporate them in this type of model. Obviously, the analysis of only fiscal indicators is not enough to fully assess the probability of a currency crisis. In spite of these, our empirical findings seem to provide supporting evidence for some authors, who argue that fiscal policy plays an important role in generating currency crises. The definition of a currency crisis as a period characterised by the presence of intense foreign exchange market pressure is the best definition used. This empirical definition of the currency crisis generally reflects that either a large increase in the exchange rate reflects only devaluation episodes or a combination of exchange rates and proxies for stabilising measures of the domestic currency in the general case of speculative attacks.

For future research, it would be interesting to apply the same analysis to a larger sample of countries and to a higher frequency of data, such as monthly data, as well as the refinement of the FSI to include behavioural content that would take into account endogenous private savings and investment behaviour, and thereby allow extensions to externally financed public deficits. On the other hand, one must investigate whether those fiscal imbalances in developing countries reflect deeper structural shortcomings such as soft budget constraints and inefficient tax systems.

\section{REFERENCES}

ALBERT, J. and S. CHIB (1993). "Bayesian analysis via Gibbs sampling of autoregressive time series subject to Markov mean and variance shifts", Journal of Business and Economic Statistics 11 (1), pp. 1-15.

AZIZ, J., F. CARAMAZZA and R. SALGADO (2000). "Currency crises: In search of common elements", Working Paper WP/00/67, International Monetary Fund.

BIRD, G. and A. MANDILARAS (2006). "Regional heterogeneity in the relationship between fiscal imbalances and foreign market pressure", World Development 34 (7), pp. 1171-1181.

BROOME, S. and B. MORLEY (2004). "Stock prices as a leading indicator of the East Asian financial crisis", Journal of Asian Economics 15, pp. 189-197.

BURKART, O. and V. COUDERT (2002). "Leading indicators of currency crises for emerging countries", Emerging Markets Review 3, pp. 107-133.

BURNSIDE, C., M. EICHENBAUM and S. REBELO (2000). "On the fundamentals of self-fulfilling speculative attacks", Working Paper 7554, National Bureau of Economics Research.

BURNSIDE, C., M. EICHENBAUM and S. REBELO (2003). "On the fiscal implications of twin crises", in Dooley, M.P. and J.A. Frankel, editors, Managing Currency Crises in Emerging Markets. University of Chicago Press, Chicago.

BURNSIDE, C., M. EICHENBAUM and S. REBELO (2006). "Government finance in the wake of currency crises", Journal of Monetary Economics 53, pp. 401-440.

CASELLA, G. and E.I. GEORGE (1992). "Explaining the Gibbs sampler", The American Statistician 46 (2), pp. 167-174.

CHANG, R. and A. VELASCO (2001). "A model of financial crises in emerging markets", Quarterly Journal of Economics 116 (2), pp. 489-514.

CORSETTI, G. and B. MACKOWIAK (2005). "A fiscal perspective on currency crises and the original sin”, in Eichengreen, B. and R. Hausmann, editors, Other People's Money: Debt Denomination and Financial Instability in emerging Market Economies. The University of Chicago Press, Chicago.

CORSETTI, G. and B. MACKOWIAK (2006). "Fiscal imbalances and the dynamics of currency crises", European Economic Review 50, pp. 1317-1338.

CROCE, E. and V.H. JUAN-RAMON (2003). "Assessing fiscal sustainability: A cross-country comparison", Working Paper WP/03/145, International Monetary Fund. 
DANIEL, B.C. (1997). "Fiscal policy and the predictability of exchange rate collapse", Working Paper WP/97/133, International Monetary Fund.

DANIEL, B.C. (2001). "A fiscal theory of currency crises", International Economic Review 42 (4), pp. 969-988.

EICHENGREEN, B., A.K. ROSE and C. WYPLOSZ (1994). "Speculative attacks on pegged exchange rates: An empirical exploration with special reference to the European Monetary System", Working Paper 4898, National Bureau of Economics Research.

EICHENGREEN, B., A.K. ROSE and C. WYPLOSZ (1996). "Contagious currency crises: First tests", Scandinavian Journal of Economics 98, pp. 463-484.

FILARDO, A.J. (1994). "Business-cycle phases and their transitional dynamics", Journal of Business \& Economic Statistics 12 (3), pp. 299-308.

FILARDO, A.J. and S.F. GORDON (1998). "Business cycle durations", Journal of Econometrics 85, pp. 99-123.

FLOOD, R. and P. GARBER (1984). “Collapsing exchange rate regimes: Some linear examples”, Journal of International Economics 17, pp. 1-13.

FLOOD, R. and N. MARION (1996). "Speculative attacks: Fundamentals and self-fulfilling prophecies", Working Paper 5789, National Bureau of Economic Research.

FRANKEL, J.A. and A.K. ROSE (1996). "Currency crashes in emerging markets: An empirical treatment", Journal of International Economics 41, pp. 351-366.

GIRTON, L. and D. ROPER (1977). "A monetary model of exchange market pressure applied to the postwar Canadian experience", American Economic Review 67, pp. 537-548.

GOLDFAJN, I. and R.O. VALDES (1997). “Are currency crises predictable?”, Working Paper WP/97/159, International Monetary Fund.

HAMILTON, J.D. (1989). "Analysis of time series subject to changes in regimes", Econometrica 57 (2), pp. 357-384.

HAMILTON, J.D. (1991). "A Quasi-Bayesian approach to estimating parameters for mixtures of normal distributions", Journal of Business and Economic Statistics 9, pp. 7-39.

KAMINSKY, G. and C. REINHART (1999). "The twin crises: The causes of banking and balance of payments problems", American Economic Review 89 (3), pp. 473-500.

KRUGMAN, P. (1979). "A model of balance of payments crises", Journal of Money, Credit and Banking 11 , pp. 311-325.

KRUGMAN, P. (1996). Are currency crises self-fulfilling? In NBER Macroeconomic Annual, volume 2, pp. 345-378.

MANDILARAS, A. and G. BIRD (2008). "Public debt and foreign exchange pressures in Latin America: does debt matter?", Journal of International Development 20 (5), pp. 613-627.

MARINI, G. and G. PIERSANTI (2003). "Fiscal deficits and currency crises", Working Paper $\mathrm{N}^{\circ} 15$, CEIS Tor Vergata.

NASHASHIBI, K. and S. BAZZONI (1993). "Alternative exchange rate strategies and fiscal performance in Sub-Saharan Africa", Working Paper WP/93/68, International Monetary Fund.

OBSTFELD, M. (1986). "Rational and self-fulfilling balance of payments crises", American Economic Review 76, pp. 72-81.

OBSTFELD, M. (1996). "Models of currency crises with self-fulfilling features", European Economic Review 40, pp. 1037-1048.

RANGVID, J. (2001). "Second generation models of currency crises", Journal of Economic Survey 15 (5), pp. 613-641.

SIWINSKA, J. (2000). Currency crises and fiscal imbalances: The transition countries perspective. Studies and Analyses 219, Center for Social and Economic Research.

SY, A.N. (2004). "Rating the rating agencies: Anticipating currency crises or debt crises?", Journal of Banking \& Finance 28, pp. 2845-2867.

VAN WIJNBERGEN, S. (1991). "Fiscal deficits, exchange rate crises and inflation", Review of Economic Studies 58 (1), pp. 81-92. 